\title{
Pola Interaksi Guru Dengan Peserta Didik Perspektif Alquran Surah Luqman Ayat 12-19
}

\author{
Sunardi \\ Sekolah Tinggi Ilmu Tarbiyah al Urwatul Wutsqo Bulurejo Jombang, Indonesia \\ Sunardi.ppuw@gmail.com \\ Khairul Fatihin \\ Madrasah Aliyah Islahul Ikhwan NW Mispalah Praya Barat Daya \\ Lombok Tengah, Indonesia \\ Fatihinkhairul2@gmail.com
}

\begin{abstract}
Digging and studying more intensely what is contained in the Koran, then we will find various kinds of messages related to education, one of which is an interesting story about the process of educational interaction and learning between father and son. In this story, if we look at the philosophical meaning, we will find several concepts, patterns or models of education. In the Koran, Luqman verses 12-19. Describe the story of how God rewards the figure of the father by perpetuating his name as the name of the Qur'anic story because of his diligent efforts to provide education and learning to his children with noble lessons. The focus that will be examined in this study is the pattern of teacher interaction with students from the perspective of the Qur'an Surah Luqman verses 12-19. This research is a research library research, which is collecting theoretical data as a scientific presentation carried out by selecting literature related to research. Technical analysis of data uses content analysis, analyzes critically the relevant data. This research concludes that the Pattern of Teacher Interaction with Students Perspective of Surah Luqman Alquran Verses 12-19, the author can draw conclusions that: a. the teacher's role in learning is the teacher as an educator, the teacher as a guide, and the teacher as an advisor. $b$. the values of education are the education of faith (faith), religious education, and moral education, $c$. teacher interaction patterns with students used are one-way relationship patterns.
\end{abstract}

Keywords: Patterns, Interactions, Students, perspectives.

\section{Pendahuluan}

Manusia adalah makhluk ciptaan Allah. Manusia dan alam semesta bukanlah terjadi dengan sendirinya. Tujuan utama pendidikan adalah menghasilkan kepribadian manusia yang matang secara intelektual, emosional dan spiritual. Mencapai akhlak yang sempurna adalah tujuan sebenarnya dari pendidikan agama Islam. Akhlak adalah budi pekerti, kebiasaan, atau segala sesuatu yang sudah menjadi tabi'at. (Mochammad Shofwan Hidayatulloh, 2015, p.3) 
Akhlak dalam Islam menempati posisi yang sangat tinggi, karena kesempurnan seorang muslim itu ditentukan oleh kualitas akhlaknya. Semakin tinggi akhlaknya berarti semakin berkualitas iman seseorang dan demikian juga sebaliknya. Islam menganjurkan muslim untuk memiliki nilai-nilai akhlakul karimah dengan merujuk kepada pribadi Rasulullah Saw.

Selanjutnya diikuti pula dengan mengamalkan segala perintah Allah yang ada didalam Alquran dan menjauhi segala apa yang dilarang-Nya. Dengan kata lain beriman pada kitab-kitab, khususnya Alquran, harus disertai dengan berakhlak dengan akhlak Alquran, sebagaimana hal ini dilakukan oleh Nabi Muhammad Saw. (Mochammad Shofwan Hidayatulloh, 2015, p.4)

Problematika akhlak senantiasa mewarnai kehidupan manusia dari masa ke masa, dalam setiap kurun waktu dan tempat dimana muncul tokoh memperjuangkan nilai-nilai akhlak, termasuk didalamnya Rasul utusan Allah SWT, khususnya Rasulullah SAW, yang memiliki tugas dan misi utama untuk menegakkan nilai-nilai akhlak. Lemahnya iman adalah faktor utama yang mempengaruhi jeleknya akhlak manusia. (Mochammad Shofwan Hidayatulloh, 2015, p.5)

Manusia sebagai mahluk sosial membutuhkan hubungan dengan manusia yang lain. Hubungan tersebut terjadi karena manusia saling membutuhkan untuk dapat memenuhi kebutuhannya. Karena manusia tidak bisa lepas dari manusia lainnya dan tidak bisa melakukan seorang diri.Kecenderungan manusia berhubungan melahirkan komunikasi dengan manusia yang lainnya. Komunikasi terjadi karena saling membutuhkan melalui sebuah interaksi. Interaksi merupakan hubungan antar manusia yang sifat dari hubungan tersebut adalah dinamis artinya hubungan itu tidak statis, selalu mengalami dinamika. (M. Setidi Elly dan Kolip Usman, 2011, p.62)

Hidup bersama antara manusia akan berlangsung dalam berbagai bentuk komunikasi dan situasi. Dalam hidup semacam inilah terjadi interaksi. Dengan demikian kegiatan hidup manusia akan selalu dibarengi dengan proses interaksi atau komunikasi , baik interaksi dengan alam lingkungan, interaksi dengan sesamanya, maupun interaksi dengan Tuhannya, baik itu disengaja maupun tidak 
disengaja. Dari berbagai bentuk interaksi, khususnya mengenai interaksi yang disengaja, ada istilah interaksi edukatif.Interaksi edukatif ini adalah interaksi yang berlangsung dalam suatu ikatan untuk tujuan pendidikan dan pengajaran. Oleh karena itu interaksi edukatif perlu dibedakan dari bentuk interaksi yang lain. Dalam arti yang lebih spesifik pada bidang pengajaran, dikenal adanya istilah interaksi belajar-mengajar dengan kata lain apa yang dinamakan interaksi edukatif, secara khusus adalah sebagai interaksi belajar-mengajar”. (Sardirman, 2000, p.1)

Interaksi belajar-mengajar mengandung suatu arti adanya kegiatan interaksi dari tenaga pengajar yang melaksanakan tugas mengajar di satu pihak, dengan warga belajar (siswa/peserta didik/subjek belajar), yang sedang melaksanakan kegiatan belajar di pihak lain. Guru dan peserta didik memang dua figur manusia yang selalu hangat dibicarakan dan tidak akan pernah absen dari agenda pembicaraan masyarakat. Guru tidak hanya disanjung dengan keteladanannya, tetapi ia juga dicaci-maki dengan sinis hanya karena kealpaanya berbuat kebaikan, meski kesalahan itu bak setitik noda semata. Keburukan perilaku peserta didik cenderung diarahkan pada kegagalan guru membimbing dan membina peserta didiknya. Padahal warna perilaku peserta didik yang buruk, itu dapat terkonsumsi dari multisumber/berbagai faktor.

Guru dan peserta didik adalah frase yang serasi, seimbang dan harmonis. Hubungan keduanya berada dalam relasi kewajiban yang saling membutuhkan. "Dalam perpisahan raga, jiwa mereka bersatu sebagai dwitunggal, guru mengajar dan peserta didik belajar dalam proses interaksi edukatif yang menyatukan langkah mereka kesatu tujuan yaitu kebaikan". Dengan demikian kemuliannya guru dapat meluruskan pribadi peserta didik yang dinamis agar tidak membelok dari kebaikan. (Syaiful Bahri Djamarah, 2000, p.2)

Berkaitan dengan pola interaksi guru dengan peserta didik yang sesuai dengan ajaran Alquran, yaitu perilaku atau moral yang berdasarkan Alquran. Persoalan yang paling mendasar yang terjadi di sekolah terkadang masih ada beberapa guru yang memperlakukan muridnya secara diskriminatif. Ia memperlakukan muridnya dengan pilih kasih dan membeda-bedakan anak yang 
cerdas, cantik, berpangkat, anak kesayangan, dan lain sebagainya. Padahal mereka seharusnya merasakan bahwa sekolah bagi mereka merupakan tempat belajar yang menyenangkan.

Seharusnya murid ketika di sekolah hendakanya dihargai, dipahami, dan tidak dibodoh-bodohkan maupun diejek, khususnya anak dari masyarakat miskin. Begitu pula dengan sikap murid yang kurang baik dalam berinteraksi dengan guru, seperti halnya dengan menjaga sopan santun baik tutur kata maupun tingkah laku murid terhadap guru.

Kalau kita sedikit lebih intens menggali dan mengkaji apa yang terkandung dalam Alquran, maka kita akan menjumpai beberapa model pendidikan, salah satu di antaranya adalah sebuah kisah yang menarik mengenai proses interaksi pendidikan dan pembelajaran antara ayah dan anak. Dalam kisah ini jika di perhatikan dari makna filosofis maka kita akan temukan beberapa konsep, pola atau model pendidikan, persisnya tersebut terdapat pada Alquran surah Luqman ayat 12-19. dalam kisah tersebut sampai-sampai Allah memberi penghargaan kepada sang ayah dengan mengabadikan namanya sebagai nama kisah Alquran karena usahanya yang gigih memberi nasehat atau pengajaran kepada anaknya dengan pelajaran yang mulia.

Alquran surah Luqman ayat 12-19 menjadi pertimbangan bagi penulis sebagai bahan penelitian karena sosok Luqman adalah figure yang selalu memberikan contoh yang terbaika pada anakanya dan memberikan pelajaran kepada anaknya ajaran ketauhidan untuk mendekatkan diri kepada Allah SWT dan merenungkan alam yang ada disekelilingnya, sehingga ia mendapat kesan yang mendalam. Berdasarkan latar belakang diatas, penulis ingin mencoba menyusun skripsi dengan judul "Pola Interaksi Guru dengan Peserta Didik Perspektif Alquran Surah Luqman Ayat 12-19."

\section{Fokus Penelitian}

Bagaimana pola interaksi guru dengan peserta didik perspektif Alquran surah Luqman ayat 12-19? 


\section{Metode Penelitian}

Penelitian ini untuk memperoeh pemahaman yang utuh, mendalam dan menyeluruh terhadap fokus penelitian maka peneliti menggunakan paradigma library research, yaitu mengumpulkan data teoritis sebagai penyajian ilmiah yang dilakukan dengan memilih literature yang berkaitan dengan penelitian. Penggalian dan pengumpulan data-data yang relevan diambil sebagai sumber pene;itian yaitu tulisan, baik dari majalah, tulisan ilmiah dan lain-lain yang bersangkutan dengan fokus penulisan, dan pembahasan. Teknis analisi data penelitian ini menggunakan teknik berfikir atau metode deskriptif, content analysis, dan kritis terhadap data yang bersifat kepustakaan untuk mengkaji atau mendeskripsikan dan menganalisa dengan nalar kritis untuk mencari data relevan.

\section{Pembahasan}

\section{Pola Interaksi Guru dengan Peserta Didik Perspektif Alquran Surah Luqman Ayat 12-19}

1. Peran guru dalam pembelajaran dalam Alquran surah Luqman ayat 12-19 a. Guru sebagai pendidik

Guru sebagai pendidik adalah guru menjadi panutan, dan contoh bagi para peserta didik. Oleh karena itu, sebagai seorang guru harus mempunyai tanggung jawab, kewibawaan, dan kedisiplinan dalam mendidik. Sebagaimana yang terdapat dalam surah Luqman ayat 13 bahwa Luqman merupakan contoh pendidik yang ideal. Ia bertindak sebagai orang tua sekaligus sebagai pendidik bagi anaknya. Dalam ayat tersebut, Luqman mendidik anaknya supaya menyembah Allah dan tidak menyekutukan Allah. Setelah itu dalam surah Luqman ayat 17 juga menjelaskan bahwa Luqman mendidik anaknya untuk beribadah kepada Allah dengan memerintantahnya supaya melaksanakan sholat, yaitu beribadah menyembah hanya kepada Allah semata dengan tulus ikhlas dan murni semata-mata hanya untuk-Nya.

E. Mulyasa mengatakan dalam bukunya yang berjudul "Menjadi Guru Profesional" bahwa guru sebagai seorang pendidik adalah orang yang menjadi tokoh, panutan, dan identifikasi bagi para peserta didik, dan lingkungannya. Oleh karena itu, guru harus memiliki standar kualitas 
pribadi tertentu, yang mencakup tanggung jawab, wibawa, mandiri, dan disiplin. (Mulyasa, 2005, p.37)

Berdasarkan penjelasan tersebut maka guru sebagai seorang pendidik hendaknya mendidik muridnya untuk menyembah hanya kepada Allah dan tidak mepersekutukan-Nya dengan sesuatu yang lain. Karena jika mempersekutukan Allah maka akan menjadi orang yang zalim kepada Allah SWT. hendaknya juga sebagai seorang pendidik juga diharapkan mendidik muridnya supaya beribadah kepada Allah SWT. yaitu memerintahkannya untuk melaksanakan sholat sebagai bukti keimanannya kepada Allah SWT. sebagai seorang pendidik jangan sampai mendidik dengan cara menggunakan kekerasan dan suara yang membentak bentak. Tetapi seorang pendidik hendaknya mendidik dengan cara lemah lembut, dengan perkataan yang halus dan penuh kasih sayang.

b. Guru sebagai pembimbing

Guru sebagai pembimbing adalah orang yang memberikan arahan atau petunjuk kepada peserta didik untuk mencapai tujuan yang akan di tempuh dalam pembelajaran. Kesuksesan seorang peserta didik berdasarkan adanya bimbingan seorang guru, karena guru merupakan orang yang menjadi petunjuk arah dalam perjalanan pembelajaran. Oleh karena itu, guru merupakan orang yang bertanggung jawab memberi bimbingan atau bantuan kepada peserta didik dalam perkembangan jasmani dan ruhaninya supaya peserta didik tersebut bisa mencapai kedewasaannya. Hal ini terdapat dalam surah Luqman ayat 12-19 yang menggambarkan bahwa Luqman sebagai pembimbng untuk anaknya, yaitu Luqman membimbing anaknya supaya tidak menjadi orang yang syirik dan zalim, Luqman membimbing anaknya supaya selalu beribadah kepada Allah, dan Luqman juga membimbing anaknya supaya tidak menjadi orang yang sombong, angkuh dan membanggakan diri.

Penjelasan tersebut sebagaimana yang dikemukakan oleh Mulyasa, bahwa guru dapat diibaratkan sebagai pembimbing perjalanan (journey), yang berdasarkan pengetahuan dan pengalamannya bertanggung jawab atas 
kelancaran perjalanan itu. Istilah perjalanan merupakan suatu proses belajar, baik dalam kelas maupun di luar kelas yang mencakup seluruh kehidupan. (Mulyasa, 2005, p.40-41)

Bimbingan Luqman kepada anaknya di atas merupakan sebagai gambaran bagi para guru supaya membimbing peserta didik agar menempuh jalan yang benar tidak tesasat. Guru membimbing peserta didik mengenai akidah (keimanan) kepada Allah swt, yaitu menyembah atau beribadah hanya kepada Allah semata bukan pada yang lain, tidak menyekutukan-Nya dengan sesuatu apa pun supaya peserta didik tidak menjadi orang yang zalim, membimbing peserta didik supaya selalu mendirikan sholat, mengerjakan kebaikan dan menjauhi perbuatan keji dan mungkar, mengajak pada kebaikan dan mencegah pada kemungkaran, kemudian guru membimbing peserta didik supaya selalu bersabar dalam mengerjakan sholat dan menjalankan amr ma'ruf nahi munkar, karena di dalam itu semua pasti terdapat banyak gangguan dan cobaan, dan guru juga harus membimbing peserta didik supaya tidak menjadi orang yang sombong, angkuh, dan membanggakan diri.

c. Guru sebagai penasehat

Guru merupakan seorang penasehat bagi peserta didiknya. Karena setiap peserta didik yang mempunyai masalah membutuhkan nasehat seorang guru supaya bisa mengambil keputusan yang tepat terhadap masalah yang dihadapi. Semakin efektif guru menangani setiap permasalahan maka semakin banyak kemungkinan peserta didik berpaling kepadanya untuk mendapatkan nasehat dan kepercayaan diri. Setiap peserta didik melakukan kesalahan dan mempunyai masalah maka seoarang guru mempunyai tanggung jawab untuk memberinya nasehat. Guru sebagai penasehat digambarkan dalam surah Luqman ayat 12-19 ketika Luqman memberikan nasehat kepada anaknya supaya menghindari perbuatan syirik yaitu tidak mempersekutukan Allah, memerintahkan anaknya untuk mendirikan sholat, amr ma'ruf nahi mungkar dan bersabar atas segala gangguan, dan Luqman menasehati anaknya supaya tidak memalingkan 
muka dari manusia karena sombong, tidak angkuh dalam berjalan, serta menasehati anaknya supaya sederhana dalam berjalan dan melunakkan suara ketika berbicara.

Berdasarkan penjelasan di atas, maka bisa dipahami bahwa di antara kewajiban guru adalah memberi nasehat dan pelajaran kepada peserta didiknya, sehingga peserta didiknya dapat menempuh jalan yang benar, dan terhindar dari kesesatan. Oleh karena itu hal pertama yang harus dilakukan oleh seorang guru adalah memeberikan kepada muridnya pelajaran mengenai akidah (keimanan) kepada Allah SWT yaitu tidak menyekutukanNya dengan sesuatu yang lain. Seorang guru juga diharapkan memberikan nasehat kepada peserta didiknya supaya melakukan amal shalih, menjauhi kejelekan-kejelekan, dan supaya percaya terhadap balasan Allah SWT. Guru hendaknya selalu menasehati peserta didiknya supaya selalu mendirikan sholat dengan sebaik-baiknya, sehingga diridhoi Allah, berusaha mengajak sesama mengerjakan perbuatan-perbuatan baik yang diridhoi Allah, serta mencegah mereka agar tidak mengerjakan perbuatan-perbuatan dosa dan hendaknya guru menasehati peserta didiknya untuk selalu bersabar dan tabah terhadap segala macam cobaan yang menimpa. Nasehat yang terakhir seoarang guru yang terkandung dalam surah Luqman ayat 12-19 adalah guru hendaknya memberikan nasehat kepada peserta didiknya tentang akhlak sopan santun atau budi pekerti yang baik terhadap sesama dengan cara memerintahkan peserta didiknya supaya jangan sekali-kali bersifat angkuh dan sombong, dan lemah lembut dalam berbicara, sehingga orang yang melihat dan mendengarnya merasa senang dan tentram hatinya.

Peran guru sebagai penasehat ini dikuatkan juga dengan pendapat Mulyasa bahwasa guru adalah seorang penasehat bagi peserta didik. Menjadi seorang guru berarti menjadi penasehat dan menjadi orang kepercayaan, kegiatan pembelajaranpun meletakkannya pada posisi tersebut. Peserta didik senantiasa berhadapan dengan kebutuhan untuk membuat keputusan, dan dalam prosesnya akan lari kepada gurunya. Peserta didik akan menemukan sendiri dan secara mengherankan, bahkan mungkin 
menyalahkan apa yang ditemukannya, serta akan mengadu kepada guru sebagai orang kepercayaan. (Mulyasa, 2005, p.43-44)

2. Materi pendidikan dalam Alquran surah luqman ayat 12-19

a. Pendidkan akidah (keimanan)

Pendidikan akidah merupakan pendidikan yang pertama dan utama dilakukan seorang guru kepada peserta didiknya. Pendidikan ini bertujun untuk liberasi diupayakan melalui usaha menanamkan keimanan kepada Allah dan melarang syirik. Akidah (keimanan) adalah suatu keyakinan yang di anut oleh seseorang dan menjadi pemegang hidupnya.

Sebagaimana yang dikemukakan oleh As'aril Muhajir dalam bukunya yang berjudul "Ilmu Pendidikan Perspektif Kontekstual" bahwa akidah merupakan keyakinan keagamaan yang di anut oleh seseorang dan menjadi landasan segala bentuk aktivitas, sikap, pandangan, dan pemegang hidupnya. Akidah adalah apa yang terlintas dalam hati, dibenarkan melalui lisan, serta dibuktikan dengan amal perbuatan. Didahulukannya pendidikan akidah ini agar anak menjadi generasi mukmin dan muttaqin (orang yang beriman dan bertakwa kepada Allah). Oleh karena itu, setiap orang tua atau pendidikan hendaknya memperhatikan pendidikan akidah bagi anaknya demi masa depan anaknya tersebut. (As'aril Muhajir, 2011, p.169-176)

Pendidikan akidah (keimanan) yang terdapat dalam surah Luqman ayat 12-19 adalah pendidikan akidah iman kepada Allah dan pendidikan akidah iman kepada hal yang ghoib.

1) Iman kepada Allah

Iman kepada Allah adalah percaya dan membenarkan dengan hati bahwa Allah ada dengan segala sifat keagungan dan kesempurnaannya, kemudian diakui dengan lisan dan dibuktikan dengan amal perbuatan di dunia nyata. Dalam surah Luqman ayat 13 memberikan gambaran kepada para guru supaya pendidikan akidah berupa iman kepada Allah sangat perlu diberikan kepada peserta didik supaya tidak mempersekutukan Allah, karena tersebut merupakan perbuatan zalim. Dalam ayat 13 ini zalim berarti beribadah kepada 
selain Allah.

Hal ini dikuatkan dengan pendapat Abu Bakar Jabir al-Jazairi dalam buku tafsirnya yang berjudul "Tafsir Alquran al-Aisar" yang mengatakan bahwa mempersekutukan Allah adalah perbuatan zalim. Zalim adalah meletakkan sesuatu tidak pada tempatnya, dimana hal itu berakibat pada kerusakan dan kerugian yang besar. Beribadah kepada selain Allah adalah meletakkan sesuatu bukan pada tempatnya, karena yang berhak untuk diibadahi dan disembah hanyalah Allah dan itulah hak Allah atas hamba-Nya, sebagai balasan atas diciptakannya mereka, atas risky dan karunia-Nya, serta pemeliharaan dan penjagaan Allah dalam kehidupan mereka. (Abu Bakar Jabir al-Jazairi, 2012, p.712) Begitu pula dengan yang dikemukakan oleh M. Quraish Shihab bahwa perlunya menghindari perbuatan syirik/mempersekutukan Allah. Karena larangan ini sekaligus mengandung pengajaran tentang wujud dan keesaan Tuhan. Bahwa redaksi pesannya berbentuk larangan, jangan mempersekutukan Allah untuk menekankan perlunya meninggalkan sesuatu yang buruk sebelum melaksanakan yang baik. (M. Quraish Sihab, 2002, p.298)

2) Iman kepada yang ghaib Iman kepada yang ghaib merupakan meyakini dengan sepenuh hati kepada hal yang ghaib, yang tidak dapat dijangkau oleh panca indera dan tidak bisa dicapai oleh akal biasa, tetapi hanya bisa diketahui berdasarkan wahyu (khabar). Oleh karena itu, pendidikan akidah juga harus ditanamkan melalui upaya memberikan keyakinan bahwa semua amal perbuatan pada manusia akan dipertanggungjawabkan dihadapan Allah. Yaitu percaya adanya Allah SWT yang maha ghoib tak terlihat. Hal ini digambarkan dalam surah Luqman ayat 16, ketika Luqman berwasiat kepada anaknya bahwa segala perbuatan yang dilakukannya didunia, Allah akan membalasnya karena Alla maha mengetahui segala sesuatu.

Berdasarkan penjelasan di atas, sebagai seorang guru selain 
menanamkan pendidikan akidah tentang iman kepada Allah seorang guru juga hendaknya menanamkan kepada peserta didik tentang maha ghoibnya Allah, percaya atas adanya Allah yang selalu mengawasi gerak geriknya. Oleh karena itu, sebagai seorang guru hendaknya memerintahkan peserta didiknya supaya beramal baik, karena apa yang dilakukan manusia, dari yang besar sampai yang sekecilkecilnya, yang tampak dan yang tidak tampak, yang terlihat dan yang tersembunyi, baik di langit maupun dibumi, pasti diketahui Allah. Oleh karena itu, Allah pasti akan memberikan balasan yang setimpal dengan perbuatan manusia itu. perbuatan baik akan dibalas dengan surga, sedang perbuatan jahat dan dosa akan dibalas dengan neraka.

Hal ini dikuatkan dengan pendapat M. Quraish Sihab dalam buku tafsirnya bahwa Allah tidak dapat dilihat, paling tidak dalam kehidupan di dunia. Nabi Musa as. Pernah memohon untuk melihat Allah, namun begitu Allah penampakkan kebesaran dan kekuasaanNya atau pancaran cahaya-Nya ke sebuh gunung, gunung tersebut hancur berantakan. Allah juga Lathif yang berarti tidak dapat diketahui hakikat dzat dan sifat-sifat-Nya. Walhasil, seperti tulisan seorang alim, "Dia tertutup dari pandangan mata dengan selendang keagungan-Nya, terlindungi dari jangkauan akal dengan pakaian kebesaran-Nya, terbatasi dari bayangan imajinasi oleh cahaya keindahan-Nya, dan karena cemerlangnya pancaran cahaya-Nya, Dia adalah yang maha ghoib. (M. Quraish Sihab, 2002, p.307)

b. Pendidikan ibadah

Pendidikan ibadah merupakan pendidikan yang berkaitan dengan bagaimana seorang hamba menjalankan perintah Allah dan menjauhi larangan-Nya, sebagai bentuk interaksi dengan sang pencipta. Pendidikan ibadah sangat penting diberikan kepada peserta didik supaya bisa mendekatkan diri kepada Allah swt. Hal ini digambarkan dalam surah Luqman ayat 12 dan 17 oleh Luqman dan anaknya. Luqman memberikan pendidikan ibadah kepada anaknya supaya bisa bersyukur kepada Allah dan 
supaya selalu melaksanakan sholat, amrar ma'ruf nahi mungkar dan sabar.

Penjelasan di atas dikuatkan dengan teori M. Qiraish Sihab dalam buku tafsirnya bahwa ibadah adalah segala amal perbuatan yang dilakukan karena melakukan perintah Allah. Ibadah adalah tujuan utama Allah menciptakan manusia. Karena ibadah merupakan perbuatan yang dilakukan sebagai usaha menghubungkan dan mendekatkan diri kepada Allah SWT sebagai Tuhan yang disembah. Ibadah juga dapat diartikan sebagai pengabdian dan penyembahan. (As'aril Muhajir, 2011, p.176-177)

Berdasarkan paparan di atas maka sebagai seorang guru hendaknya memberikan pendidikan ibadah kepada peserta didik supaya selalu bisa bersyukur kepada Allah atas semua nikmat yang telah diberikan kepadanya supaya tidak menjadi orang yang kufur (tidak mensyukuri nikmat). Setelah mengajarkan ibadah syukur, sebagai seorang guru hendaknya memberikan pendidikan ibadah yaitu Selalu mendirikan sholat dengan sebaik-baiknya, sehingga diridhoi Allah. Jika sholat itu diridhoi Allah, perbuatan keji dan perbuatan mungkar dapat dicegah, jiwa menjadi bersih,tidak ada kekhawatiran terhadap orang itu, dan mereka tidak akan bersedih hati jika di timpa cobaan, dan merasa dirinya semakin dekat dengan tuhannya. Kemudian seorang guru memberikan nasehat kepada peserta didik supaya selalu berusaha mengajak sesama manusia mengerjakan perbuatanperbuatan baik yang diridhoi Allah, berusaha membersihkan jiwa dan mencapai keberuntungan, serta mencegah mereka agar tidak mengerjakan perbuatan-perbuatan dosa. Sebagai seorang guru juga berkewajiban untuk menasehati peserta didik supaya selalu bersabar dan tabah terhadap segala macam cobaan yang menimpa, akibat dari mengajak manusia berbuat baik dan meninggalkan perbuatan yang mungkar, baik cobaan itu dalam bentuk kesenangan dan kemegahan maupun dalam bentuk kesengsaraan dan penderitaan.

c. Pendidikan Akhlak

Pendidikan akhlak adalah pendidikan yang berkaitan dengan tingkah laku, sopan santun peserta didik. Akhlak yang baik bisa diperoleh peserta 
didik melalui pembiasaan dan melatih diri untuk melakukan preilakuperilaku yang baik. Dengan melaui pembiasaan tersebut maka akan muncul atau terbentuk akhlak yang baik didalam diri peserta didik.oleh karena itu seorang guru mempunyai kewajiban untuk memberikan pelajaran dan mendidik peserta didik tentang akhlak, baik itu akhlak kepada Allah dan akhlak kepada sesama.

Hal ini dikuatkan dengan teori yang dikemukakan oleh As'aril Muhajir bahwa akhlak Akhlak adalah tingkah laku yang lahir dari manusia dengan sengaja, tidak dibuat-buat, dan telah menjadi kebiasaan. Akhlak itu ada yang baik dan ada yang buruk. Akhlak yang baik disebut adab. Kata $a d a b$ juga digunakan dalam arti etika, yaitu tata cara sopan santun dalam masyarakat guna memelihara hubungan baik antar mereka. (As'aril Muhajir, 2011, p.179)

Akhlak kepada Allah digambarkan dalam surah Luqman ayat 12 yaitu mensyukuri segala nikmat Allah. Akhlak yang baik ditanamkan pertama kali adalah bagaimana seorang anak tahu terimakasih kepada Tuhannya. Dan ayat 14 menggambarkan pendidikan akhlak kepada sesama yaitu perintah Luqman kepada anaknya supaya berbuat baik terhadap kedunya. Kemudian pendidikan akhlak kepada sesama juga digambarkan pada ayat 18 dan ayat 19 ketika Luqman memerintahkan anaknya supaya tidak memalingkan muka ketika berbicara, tidak berjalan di muka bumi ini dengan angkuh, tetapi sederhanalah dalam berjalan, dan lunakkanlah suaramu ketika berbicara.

Berdasar penjelasan di atas maka seorang guru hendaknya meberi nasehat kepada peserta didik supaya selalu bersyukur kepada Allah atas segala nikmat yang telah diberkan kepadanya, baik dalam keadaan apa pun. Karena syukur itu merupakan salah satu akhlak kepada Allah swt. Sebagai seorang guru juga hendaknya memberikan pendidikan akhlak kepada peserta didik terhadap sesama. akhlak kepada sesama ini di mulai dari yang terdekat yaitu kedua orang tua. Akhlak kepada orang tua maksudnya adalah berbuat baik, berbakti dan mentaati keduanya dalam hal yang ma'ruf, 
menyambung silaturrahmi, tidak membentak ketika berbicara dengan keduanya, serta tidak menyakitinya. Tetapi jika keduanya memerintahkan kepada kemungkaran maka boleh tidak mentaatinya. Selanjutnya sebagai seorang guru hendaknya memberikan pendidikan akhlak kepada peserta didik yaitu akhlak terhadap sesama supaya tidak bersifat angkuh ketika berjalan dan sombong, tidak membanggakan diri dan tidak memandang rendah orang lain. Akan tetapi hendaklah berjalan secara wajar, tidak tidak dibuat-buat dan kelihatan angkuh atau sombong, dan lemah lembut dalam berbicara, sehingga orang yang melihat dan mendengarnya merasa senang dan tentram hatinya. Berbicara dengan sikap keras, angkuh, dan sombong dilarang Allah karena gaya bicara yang semacam itu tidak enak didengar, menyakitkan hati diibaratkan Allah dengan suara keledai yang tidak nyaman didengar.

3. Pola interaksi guru dengan peserta didik

Pola interaksi guru dengan peserta didik adalah gambaran antara guru dengan peserta didik dalam berinteraksi yang memeberikan timbal balik kepada keduanya di dalam pembelajaran. Dengan melakukan interkasi tersebut maka muncullah suatu komukasi diantara guru dengan peserta didik. Dalam surah Luqman ayat 12-19 terdapat pola interaksi guru dengan peserta didik yaitu Luqman diilustrasikan sebagai guru sedangkan anaknya sebagai peserta didik.

Pola interaksi guru dengan peserta didik dalam Alquran surah Luqman ayat 12-19 adalah menggunakan pola hubungan satu arah. Hubungan satu arah ini biasanya di dominasi oleh guru, karena proses pembelajaran berlangsung hanya guru yang berperan aktif yaitu menyampaikan materi pembelajaran sehingga dominasi peran siswa menjadi lebih pasif, siswa mendengarkan dan guru menyampaikan. Dimana sikap seperti itu merupakan bentuk ketawadhuan seorang peserta didik kepada guru.

Hal ini dikuatkan dengan teori menurut Sumiati dan Asra dalam bukunya yang berjudul “ Metode Pembelajaran” bahwa pola hubungan satu arah adalah dari guru kepada siswa jadi suasana kelas biasanya tenang dan 
tertib, tidak ada suara, kecuali yang ditimbulakan oleh guru keadaan ini disebut pola guru-siswa dengan komunikasi sebagai aksi/satu arah. Dapat disimpulkan bahwa pola satu arah atau komunikasi sebagai aksi merupakan pola yang didominasi oleh pihak guru selama proses pembelajaran. Guru hanya menerangkan atau menyampaikan materi pembelajaran dan siswa mendengarkan dan menyimak dengan baik. (Sumiati dan Asra, 2009, p.79)

\section{Kesimpulan}

Berdasarkan dari keseluruhan uraian dan analisis tentang Pola Interaksi Guru dengan Peserta Didik Perspektif Alquran Surah Luqman Ayat 12-19, penulis dapat mengambil kesimpulan bahwa: a. peran guru dalam pembelajaran adalah guru sebagai pendidik, guru sebagai pembimbing, dan guru sebagai penasehat. $b$. nilai-nilai pendidikannya adalah pendidikan akidah (keimanan), pendidikan ibadah, dan pendidikan akhlak, c. Pola interaksi guru dengan peserta didik yang digunakan yaitu pola hubungan satu arah.

\section{Daftar Rujukan}

Elly M. Setidi dan Kolip Usman, 2011. "Pengantar Sosiologi: Pemahaman Fakta dan Gejala Permasalahan Sosial: Teori, Aplikasi, dan Pemecahannya," Jakarta : Kencana Prenada Media Grup

Djamarah Syaiful Bahri, 2000. "Guru dan Anak Didik dalam Interaksi Edukatif," Jakarta: Rineka Cipta

Jabir al-Jazairi Abu Bakar, 2012. Tafsir Alquran Al-Aisar, Jakarta: Darus Sunnah

Mulyasa, 2005. Menjadi Guru Profesional Menciptakan Pembelajaran Kreatif dan Menyenangkan, Bandung: PT Remaja Rosdakarya

Muhajir As'aril, 2011. Ilmu Pendidikan Perspektif Kontekstual, Jogjakarta: ArRuzz Media

Sardirman, 2000. "Interaksi dan Motivasi Belajar Mengajar," Jakarta:Raja Grafindo Persada

Sihab M. Quraish, 2002. Tafsir Al-Misbah, Jakarta: Lentera Hati

Sumiati dan Asra, 2009. Metode Pembelajaran, Bandung: CV Wacana 
Sunardi 